\title{
Low Prevalence of MRSA in Physiotherapy and Gym Facilities in a Greek Refugee Camp
}

M. Belovicova (Maria Belovicova)', A. Liskova (Anna Liskova)', T. Hrindova (Tatiana Hrindova)', V. Hulkova (Viera Hulkova)', J. Polonova (Jaroslava Polonova)', P. Laca (Peter Laca)', M. Kilikova (Maria Kilikova)1, D. Kalatova (Dagmar Kalatova)', A. Gallova (Andrea Gallova)', T. Bak (Tadeusz Bak)1, S. Spanik (Stanislav Spanik)', N. Bujdova (Natasa Bujdova)', V. Krcmery (Vladimir Krcmery)', P. Koleda (Peter Koleda)’, M. Olah (Michal Olah)', A. Nadourova (Annamaria Nadourova)', S. Heinecke (Sabine Heinecke)' ${ }^{1}$ K. Zoller (Katarina Zoller)²

${ }^{1}$ St. Elisabeth University $\mathrm{PhD}$ and MSc program Bratislava, Slovakia

${ }^{2}$ UNHCR refugee camp Veria, Greece

${ }^{3}$ OBE refugee camp, Mariupol, Ukraine

${ }^{4}$ University Hospital Trenčín, Slovakia

\section{E-mail address:}

katarina.zollerova@gmail.com

\section{Reprint address:}

Katarina Zoller

UNHCR Refugee Camp

Veria, Greece

Suource: Clinical Social Work and Health Intervention Pages: $35-37$
Volume: 8

Issue: 2

Cited references: 5

\section{Reviewers:}

Vitalis Okoth Odero

Catholic university of Eastern Africa, Nairobi, Kenya

Vlastimil Kozon

Allgemeines Krankenhaus - Medizinischer Universitätscampus, Vienna, Austria

\section{Key words:}

MRSA, Physiotherapy, Migrants.

\section{Publisher:}

International Society of Applied Preventive Medicine i-gap

CSWHI 2017; 8(2): 35 - 37; 10.22359/cswhi_8_2_07 @ 2017 Clinical Social Work and Health Intervention 


\section{Abstract:}

An etiology of skin and soft tissue infections (SSTI) is commonly associated with $S$. aureus and $S$. pyogenes. A wet environment, physiotherapy procedures, towels and massages are commonest risk factors. Football players often require physiotherapy procedures after a match. The aim of this study was a survey on MRSA among amateur football players in a Greek refugee camp.

\section{Conflict of interest:}

The authors whose names are listed in the title of the article certify that they have NO affiliations with or involvement in any organization or entity with any financial interest (such as honoraria; educational grants; participation in speakers' bureaus; membership, employment, consultancies, or other equity interest), or non-financial interest (such as personal or professional relationships, affiliations, knowledge or beliefs) in the subject matter or materials discussed in this manuscript.

\section{Introduction}

Football is a popular outdoor activity often used as a social intervention in refugee camps to prevent cabin fever and promote healthy social and physical interactions. However, sportsmen are at risk of acquiring SSTI usually caused by $S$. aureus. Wet towels, close contact at a match, physiotherapeutic procedures and massages are risk factors. The aim of this study was to assess the proportion of MRSA among football players in the refugee camp at Veria, Greece, which serves about 5,000-7,000 migrants waiting for asylum procedures.

\section{Patients and Methods}

Two teams of different nationalities (Iraq and Syria) regularly playing football matches in the camp were screened with skin swabs for MRSA presence. In total, 44 skin swabs were obtained after football matches and physiotherapy procedures. The samples were sent for CLSI-based testing to the National Reference Laboratory for Antimicrobial Resistance in Nitra, Slovakia.

\section{Results and discussion}

Among 44 players screened, only 8 pathogenic isolates were cultivated, two of them were $S$. aureus and other 6 Candida albicans. All S. aureus isolates were susceptible to methicillin. According to recently published surveys, prevalence of MRSA among football players is from $15 \%$ to $33 \%$. A probable explanation of our findings is a lower consumption of ATB among the migrant population. Other factors, such as lower towel use, less physiotherapy procedures, decreased overcrowding in the camp and some others, can also contribute to low MRSA prevalence in this sporting community.

\section{Conclusion}

The prevalence of MRSA skin colonization in migrants who play football in the refugee camp remains low. Increased hygiene and regular towel changing should be useful measures which will keep resistance levels low in the future. 


\section{Reference}

1. KIMULI D, MIKLOSKOVA M, SPANIK current diseases in Migrants to Austria and S, SUVADA J, CZARNECKI P (2016). Social Pathology II. Warszaw, Management University. pp 455.

2. BUJDOVA N (2015). Development and legal regulation of voluntary activities in Slovakia. Aspects of cross-border cooperation in the field of volunteering. Liraprint Ukrajina, 194 s. ISBN 978-617-596-219-0.

3. BUJDOVA N (2015). The elimination of problematic behavior of children in relation to the State Family Policy. SPAY, Social Pathology Among Youth. St. Elizabeth University of Health and Social Work Bratislava 2015 s. 93. ISBN 978-80-8132-131-3.

4. POLONOVA J (2015). Respiratory infections after camping in free nature are the Germany via Hungary in September 2015: Experience from Roszke and Vamoszabadi. In Krcmery V, Liskova A, Mrazova M, Herdics G, Khali I, Polonova J, Suvada J, Bucko L, Bibza M, Ondova P, Hajj P, Fer I. Clinical Social Work, 2015; 5(2 2015) 33-35. ISSN:2222-386X.

5. POLONOVA J (2015). Self-acceptance, self-esteem building and experiencing of healthy sexuality among youth as the prevention of an abuse in partnerships In Suvada J - Tomanek P (eds.) 2015 Social pathology among youth (abstract book) St. Elisabeth University of Health and Social Work Bratislava, 2015. ISBN 978-80-8132131-3. $73-74 \mathrm{p}$. 